29. Sulyok E. Jequier E. Prod'hom LS 1973 Thermal balance of the newborn infant in a heat-gaining environment. Pediatr Res 7:888-900

30. Chato JC 1987 Thermal properties of tissues. In: Skalak R. Chien S (eds) Handbook of Bioengineering. McGraw Hill. New York

31. Nasim-Khan M. Ahmad SH, Fakir S 1990 Comparing of temperatures at different sites in term and preterm neonates. Indian Pediatr 27:807-809

32. Singer B, Lipton B 1975 Monitoring of core temperature through the skin: a comparison with esophageal and tympanic temperatures. Bull NY Acad Sci 51:947-952

33. LaMont-Gregory E, Koppe JG. Lesnik Oberstein SY. Ryan TJ 1990 A minimally intrusive method for transcutaneous measurement of deep body temperature in infants. XII European Congress of Perinatal Medicine. Lyon. France, September 11-14

\title{
Announcement
}

\section{Society for Adolescent Medicine Annual Meeting}

The Society for Adolescent Medicine, a multidisciplinary professional organization. will hold its annual meeting in Los Angeles. CA, between March 16, 1994 and March 20,1994 at the Century Plaza Hotel. The theme for the meeting will be "Adolescents and the Media." In addition to addressing this topic, the meeting will present new material on a broad range of issues important to adolescent physical and emotional health, including AIDS and HIV medical management, teenage sexuality, eating disorders, depression, and risk-taking behaviors, which encompass drug and alcohol use and abuse. Meeting presentations include all-day institutes, 3-hour clinically oriented workshops, luncheon seminars, scientific research paper presentations and poster sessions, as well as the prestigious Gallagher Lecture Series. CME/CEUs are available. For further information, contact the Society for Adolescent Medicine, Suite 120, 19401 E. 40 Highway, Independence, MO 64055. (816) 795-8336. 